\title{
HUBUNGAN KEKUATAN TUNGKAI DAN KOORDINASI MATA KAKI DENGAN KEMAMPUAN MENGGIRING BOLA DALAM PERMAINAN SEPAKBOLA PADA MAHASISWA PENDIDIKAN KEPELATIHAN OLAHRAGA FIP UBHARA JAYA
}

\author{
Ahmad Muchlisin Natas Pasaribu ${ }^{1}$, Febi Kurniawan ${ }^{2}$
}

\section{Keywords :}

Kekuatan Tungkai;

Koordinasi Mata Kaki;

Menggiring Bola.

\section{Corespondensi Author \\ ${ }^{1}$ Universitas Bhayangkara Jakarta Raya, ahmadmuchlisinnatas@gmail.com \\ ${ }^{2}$ Universitas Singaperbangsa \\ Karawang, \\ febi.kurniawan@fkip.unsika.ac.id}

Received: Desember 2019;

Reviewed: Januari 2020;

Accepted: Februari 2020;

Published: Februari 2020;

\begin{abstract}
ABSTRAK
Penelitian ini bertujuan untuk mengetahui hubungan kekuatan tungkai dan koordinasi mata kaki dengan kemampuan menggiring bola dalam permainan sepakbola pada mahasiswa Pendidikan Kepelatihan Olahraga FIP UBHARA JAYA. Populasi pada penelitian ini adalah seluruh mahasiswa Pendidikan Kepelatihan Olahraga FIP UBHARA JAYA dengan jumlah sampel penelitian 30 orang Mahasiswa yang dipilih secara random sampling. Teknik analisis data yang digunakan adalah teknik analisis korelasi dan regresi dengan menggunakan sistem SPSS Versi 22 pada taraf signifikan 95\% atau $\alpha$ 0,05. Bertolak dari hasil analisis data, maka penelitian ini menyimpulkan bahwa: (1) hubungan kekuatan tungkai dengan kemampuan menggiring bola dalam permainan sepakbola, terbukti $r_{0}=0,647(P<\alpha 0,05)$, (2) hubungan koordinasi mata kaki dengan kemampuan menggiring boladalam permainan sepakbola., terbukti $r_{0}=0,633(P<\alpha 0,05)$, (3) hubungan kekuatan tungkai, koordinasi mata kaki dan keseimbangan dengan kemampuan menggiring boladalam permainan sepakbola., terbukti $R_{0}=0,827(P<\alpha 0,05)$.
\end{abstract}

\section{PENDAHULUAN}

Teknik dasar dalam permainan sepakbola meliputi beberapa hal. Teknik dasar yang harus dikuasai dalam bermain sepakbola adalah mengumpan, menahan bola, mengumpan lambung, menggiring bola, dan menembak bola. Secara khusus teknik menggiring bola memiliki peranan penting terhadap permainan sepakbola. Teknik dribbling merupakan keterampilan penting dan mutlak harus dikuasai oleh setiap pemain sepakbola. Dribbling merupakan kemampuan yang dimiliki setiap pemain dalam menguasai bola sebelum diberikan kepada teman untuk menciptakan peluangdalam mencetak gol. Berdasarkan hasil pengamatan selama ini sepakbola merupakan salah satu olahraga yang paling diminati oleh mahasiswa. Tetapi tidak semua mahasiswa memiliki kemampuan keterampilan dasar yang mumpuni, terutama teknik menggiring bola. Permasalahan yang terlihat, ada beberapa faktor yang mempengaruhi keterampilan menggiring bola pada mahasiswa Pendidikan Kepelatihan Olahraga FIP UBHARA JAYA salah satunya adalah koordinasi mata kaki, kemampuan mengkoordinasi mata kaki ketika menggiring bola masih selalu melihat boladan belum dapat mengalihkan perhatiannya dari arah bola. Koordinasi adalah kemampuan untuk melakukan gerakan dengan berbagai tingkat 


\section{e-ISSN: 2657-0703 dan p-ISSN: 2085-5389}

kesukarandengan cepat dan efisien dan penuh ketepatan (Rusli Lutan, 2000:77).

Faktor yang kedua adalah kekuatan otot tungkai. Kekuatan otot tungkai merupakan salah satu komponen fisik yang penting dan sangat berguna untuk meningkatkan kondisi fisik secara keseluruhan. Menuru Moehamad Sajoto (1988 : 58) kekuatan adalah komponen fisik yang menyangkut masalah seorang atlet pada saat mempergunakan otot-ototnya, menerima beban dalam waktu kerja tertentu. Faktor lain keseimbangan dibutuhkan hampir seluruh cabang olahraga yang mana setiap olahraga menerapkannya dengan cara yang berbeda. Di suatu saat ada kalanya seorang atlet harus berada pada tingkat keseimbangan yang tinggi dan ada kalanya seorang atlet harus berada pada tingkat keseimbangan yang rendah.

Sepakbola adalah suatu permainan yang dilakukan dengan jalan menyepak bola kian kemari untuk diperebutkan di antara pemainpemain yang mempunyai tujuan untuk memasukkan bola ke gawang lawan dan mempertahankan gawang sendiri agar tidak kemasukan bola. Di dalam permainan sepakbola, setiap pemain diperbolehkan menggunakan seluruh anggota badan kecuali tangan dan lengan. Karena itu berhati-hatilah di sepanjang pertandingan untuk menjaga tangan agar tidak menyentuh bola. Pemain yang diperbolehkan untuk menggunakan tangan hanya pemain yang berposisi sebagai penjaga gawang atau kipper. Itupun terbatas pada daerah persegi yang ada di sekitar gawang (kotak pinalti) yang dijaganya. Tindakan pemain pemain yang menggunakan tangan untuk menyentuh bola ini disebut handsball. Sepakbola merupakan permainan beregu yang masing-masing regu terdiri atas sebelas pemain. permainan sepakbola dimainkan dalam dua babak $(2 \times 45$ menit) dengan waktu istirahat (10 menit) diantara dua babak tersebut (Nugraha, 2012:23). Permainan sepakbola merupakan cabang beregu antar tim. Suatu tim akan dapat mengerjakan permainan yang menarik apabila dikerjakan dengan kerja sama atau team work antar pemain dengan teknik-teknik yang bagus pula. Adapun teknik dasar yang harus dikuasai oleh seorang pemain sepakbola ada dua yaitu: 1) teknik dengan bola yang meliputi mengenal bola, menendang bola, menerima bola. Menerima bola terdiri dari dua macam yaitu menghentikan bola dan mengontrol bola. Menggiring bola, menyundul bola, melempar bola, gerak tipu dengan bola, merampas atau merebut bola, dan teknikteknik khusus penjaga gawang. 2) teknik tanpa bola (lari cepat dan mengubah arah, melompat dan meloncat, gerak tipu tanpa bola, gerakangerakan khusus penjaga gawang) (Sukatamsi, 2000:16). Untuk bermain bola dengan baik pemain dibekali dengan teknik dasar yang baik. Penguasaan teknik dasar merupakan suatu syarat yang harus dimiliki oleh pemain. Keberhasilan suatu tim dalam setiap pertandingan ditentukan oleh penguasaan teknik dasar, karena dengan penguasaan teknik dasar yang baik akan tercipta permainan yang bermutu atau baik. Adapun tujuan permainan sepakbola adalah pemain berusaha memasukkan bola sebanyakbanykanya ke gawang lawan dan berusaha menjaga gawangnya agar tidak kemasukan bola. Suatu regu dinyatakan menang apabila dapat memasukkan bola terbanyak ke gawang lawannya tetapi apabila sama (misalnya 0-0 atau 1-1 dan seterusnya), maka permainan dinyatakan seri atau draw. (Agus Mukholid : 2007). Menurut Koger, Robert (2007 : 19), bahwa teknik dasar permainan sepakbola adalah mengoper (passing), menghentikan dan menerima bola (stoping), menyundul (heading), menggiring bola (dribbling), lemparan kedalam (throwing). Kemampuan teknik menendang bola besar peranannya dalam permainan sepakbola, sebab sebagian besar permainan sepakbola dilakukan dengan menendang bola. Kemampuan tendangan diperlukan untuk memasukkan bola ke gawang maupun untuk mengoperkan bola kearah teman dalam permainan sepakbola.

Kekuatan termasuk unsur yang sangat penting dalam aktivitas olahraga karena kekuatan merupakan daya penggerak, dan pencegah cidera. Selain itu kekuatan memainkan peranan penting dalam komponen-komponen kemampuan fisik yang lain misalnya power, kelincahan, dan kecepatan. Dengan demikian kekuatan merupakan faktor utama untuk menciptakan prestasi yang optimal. Menurut Ismaryati (2006:111) ada beberapa macam tipe kekuatan, yaitu: (1) Kekuatan umum adalah kekuatan sistem otot secara keseluruhan, (2) Kekuatan khusus, merupakan kekuatan otot tertentu yang berkaitan dengan gerakan tertentu pada cabang olahraga, (3) Kekuatan maksimum adalah daya tertinggi yang dapat 


\section{Volume 11 Nomor 1, Februari 2019}

ditampilkan oleh sistem syaraf otot selama kontraksi volunteer yang maksimal, (4) Daya tahan kekuatan ditampilkan dalam serangkaian gerak yang berkesinambungan mulai dari bentuk menggerakkan beban ringan berulang-ulang, dan (5) Kekuatan relative, adalah kekuatan yang ditujukan dengan perbandingan antara kekuatan absolute dengan 28 berat badan. Seperti halnya keterangan diatas, Menurut Suharno HP yang dikutip oleh Samsul Munawar (2003:8) kekuatan adalah kemampuan dari otot untuk dapat mengatasi tahanan atau beban dalam menjalankan aktivitas. Menurut Santoso Giriwijoyo (2005:72-73), latihan kekuatan otot di tinjau dari tipe kontraksi otot latihan tahanan terbagi atas tiga kategori yaitu (1) kontraksi isometrik, (2) kontraksi isotonik, (3)kontraksi isokenetik. Dari beberapa penjelasan diatas kekuatan otot tungkai adalah kemampuan sekelompok otot dalam melakukan suatu usaha gerak maupun mengatasi beban. Dalam permainan sepakbola didominasi dengan gerakan lari, menggiring bola dan menendang bola. Peranan tungkai dalam gerakan lari, menggiring bola, dan menendang bola sangat besar. Untuk itu kelompok otot tungkai merupakan faktor pendukung utama untuk keberhasilan menggiring bola yang baik. Dengan demikian diperkirakan ada hubungan antara kekuatan otot tungkai dengan keberhasilan menggiring bola dalam permainan sepakbola.

Kekuatan adalah enegri untuk melawan suatu tahanan, atau kemampuan untuk membangkitkan tegangan (tension) terhadap suatu tahanan (resistance), (Harsono, 1988 : 47). Kekuatan otot adalah unsur kemampuan fisik yang menjadikan seseorang mampu menahan beban atau tahanan dengan menggunakan kontraksi otot, (Sugianto, 1993:226). Tungkai adalah kaki atau seluruh kakinya dari pangkal paha ke bawah (Depdiknas, 2001:895). Tungkai dalam Kamus Bahasa Indonesia diartikan sebagai "kaki" atau seluruh kaki dari pangkal paha ke bawah (poewodarminto, 2003:1226). Kekuatan otot tungkai yang di maksud di sini adalah kemampuan otot untuk menerima beban dalam waktu tertentu dimana kemampuan itu dihasilkan oleh kontraksi otot yang terdapat pada tungkai dan kontraksi ini timbul untuk melakukan gerakan atau tahanan pada saat melakukan teknik sepakbola. Kekuatan otot adalah kemampuan sekelompok otot yang secara maksimal dalam sekali angkat, atau sekali dorong melawan beban yang berat. Semakin kuat seseorang, maka semakin besar pula beban yang dapat diangkat atau didorong, (Yunusul, 2004 : 1.22). Menurut Sudarminto (1992 : 60-61), tungkai terdiri dari tungkai atas yaitu pangkal paha sampai lutut dan tungkai bawah yaitu lutut sampai kaki. Otot-otot tungkai atas (otot paha) mempunyai selaput pembungkus yang sangat kuat dan disebut fasia lata yang di bagi atas 3 golongan yaitu: (1) Otot abductor terdiri dari: Muskulus abductor maldanus sebelah dalam, Muskulus abductor brevis sebelah tengah, dan Muskulus abductor longus sebelah luar. Ketiga otot ini menjadi satu yang disebut Muskulus abductor femoralis. Fungsinya menggerakkan gerakan abduksi dari femur; (2) Muskulus ekstensor (qudriseps femoris) otot berkepala. 4 otot ini merupakan otot yang terbesar terdiri dari: muskulus rektus femoris, muskulus vastus lateralis eksternal, muskulus vastus medialis internal, dan muskulus vastus intermedial, (3) Otot fleksor femoris, yang terdapat dibagian belakang paha terdiri dari: Bisep femoris, otot berkepala 2 Fungsinya membengkokkan paha dan meluruskan tungkai bawah, Muskulus semi membranosus, otot seperti selaput. Fungsinya membengkokkan urat bawah, Muskulus semi tendinosis, otot seperti urat. Fungsinya mem-bengkokkan urat bawah serta memutarkan ke dalam, dan Muskulus Sartorius, otot penjahit. Bentuknya panjang seperti pita, terdapat dibagian paha. Fungsinya eksorotasi femur, memutar keluar pada waktu lutut mengetul, serta membantu gerakan fleksi femur dan membengkokkan keluar. Otot tungkai bawah, terdiri dari: (1) Otot tulang kering depan muskulus tibialis anterior. Fungsinya mengangkat pinggir kaki sebelah tengah dan membengkokkan kaki, (2) Muskulus ekstensor talangus longus. Fungsinya meluruskan jari telunjuk ke tengah jari, jari manis dan jari kelingking kaki, (3) Otot kedang jempol, fungsinya dapat meluruskan ibu jari kaki. Urat-urat tersebut dipaut oleh ikat melintang dan ikat silang sehingga otot itu bisa membengkokkan kaki keatas. Otot-otot yang terdapat dibelakang mata kaki keatas. Otot-otot yang terdapat di belakang mata kaki luar dipaut oleh ikat silang dan ikat melintang. Fungsinya dapat mengangkat kaki sebelah luar, (4) Urat Akiles (tendos Achilles). Fungsinya meluruskan kaki di sendi tumit dan 


\section{e-ISSN: 2657-0703 dan p-ISSN: 2085-5389}

membengkokkan tungkai bawah lutut (muskulus popliteus). Otot-otot tersebut terletak dengan berpangkal pada kondilus tulang kering, melintang dan melekat di kondilus lateralis tulang paha. Fungsinya memutar tibia kedalam endorotasi. Otot ketul jari (muskulus fleksor falangus longus). Berpangkal pada tulang kering dan uratnya menuju telapak kaki dan melekat pada ruas jari kaki. Fungsinya membengkokkan jari dan menggerakkan kaki ke dalam, (5) Otot ketul empu kaki panjang (muskulus falangus longus). Berpangkal pada betis, uratnya melewati tulangjari dan melekat pada ruas empu jari. Fungsinya membengkokkan empu kaki, (6) Otot tulang betis belakang (muskulus tibialis posterior) berpangkal pada selaput antara tulang dan melekat pada pangkal tulang kaki. Fungsinya dapat membengkokkan kaki di sendi tumit dan telapak kaki disebelah kedalam, dan (7) Otot kedang jari bersama. Letaknya di punggung kak. Fungsinya dapat meluruskan jari kaki (muskulus ekstensor falangus 1-5). Jadi yang dimaksud kekuatan otot tungkai adalah komponen kondisi fisik tulang kemampuannya dalam mempergunakan otot tungkai untuk menahan beban sewaktu melakukan aktifitas kerja. Kekuatan otot tungkai memiliki peranan yang sangat penting untuk keberhasilan pemain sepakbola dalam melakukan teknik-teknik sepakbola khususnya pada waktu menggiring bola.

Dalam setiap cabang olahraga pasti memerlukan sebuah koordinasi, tidak beda dengan permainan sepakbola itu sendiri. Yang diperlukan dalam permainan sepakbola lebih dominan pada koordinasi mata kaki, karena dalam permainan ini yang banyak berperan adalah pandangan mata dan kelincahan kaki dalam mengolah bola. Menurut Rusli Lutan, dkk (2000:77), koordinasi adalah kemampuan untuk melakukan gerakan dengan berbagai tingkat kesukaran dengan cepat dan efisien dan penuh ketepatan. Sedangkan koordinasi menurut Ismaryati (2006:53) koordinasi didefinidikan sebagai hubungan yang harmonis dari hubungan yang saling pengaruh diantara kelompok-kelompok otot selama melakukan kerja, yang ditunjukkan dengan berbagai tingkat keterampilan. Koordinasi di perlukan hampir disemua cabang olahraga yang melibatkan kondisi fisik. Koordinasi juga penting bila berada dalam situasi dan lingkungan yang asing, misalnya perubahan lapangan pertandingan, peralatan, cuaca, lampu penerangan, dan lawan yang dihadapi. Koordinasi adalah kemampuan melakukan gerak pada berbagai tingkat kesukaran dengan dengan cepat dan efisien, Djoko Pekik (2002: 77) koordinasi adalah kemampuan melakukan gerak pada berbagai tingkat kesukaran dengan cepat dan tepat secara efisien. Tingkatan baik atau tidaknya koordinasi gerak seseorang tercermin dalam kemampuannya untuk melakukan suatu gerakan dengan terampil. Seorang atlet dengan koordinasi yang baik bukan hanya mampu melakukan suatu keterampilan secara sempurna, akan tetapi juga mudah dan cepat dalam melakukan keterampilan yang masih baru baginya. Koordinasi yang baik dapat mengubah dan berpindah secara cepat dari pola gerak satu ke pola gerak yang lain sehingga gerakannya menjadi efektif. Berbagai pendapat di atas dapat disimpulkan bahwa koordinasi adalah suatu kemampuan yang dimiliki seseorang (atlet) dalam memadukan berbagai macam gerak yang berbeda-beda, dengan kesulitan yang berbeda, tetapi dilakukan secara cepat dan tepat. Fungsi koordinasi dalah menghasilkan satu pola gerakan yang serasi, berirama dan kompleks maka dari itu fungsi latihan koordinasi sangat penting untuk meningkatkan kemampuan tersebut. Sedangkan koordinasi mata kaki yaitu kemampuan seseorang dalam mengintegrasikan antara pandangan mata yaitu mata sebagai pemegang fungsi utama untuk melihat objek (bola) dan sasaran, kemudian kaki sebagai gerak untuk melakukan gerakan sesuai yang diinginkan yaitu menggiring bola dalam permainan sepakbola.

\section{METODE}

Metode penelitian yang digunakan dalam penelitian ini adalah motode deskriptif korelasional. Jenis penelitian yang digunakan dalam penelitian ini adalah metode deskriptif korelasi yang artinya mencari besarnya hubungan antara dua variabel bebas (X) atau lebih dengan variabel terikat (Y) untuk mengetahui seberapa erat hubungan dan berarti atau tidaknya hubungan tersebut. Populasi pada penelitian ini adalah seluruh mahasiswa Pendidikan Kepelatihan Olahraga FIP UBHARA JAYA dengan jumlah sampel penelitian 30 orang Mahasiswa yang dipilih secara random sampling. Teknik analisis data yang digunakan adalah teknik analisis korelasi 


\section{Volume 11 Nomor 1, Februari 2019}

dan regresi dengan menggunakan sistem SPSS Versi 22 pada taraf signifikan $95 \%$ atau $\alpha 0,05$.

\section{HASIL DAN PEMBAHASAN Hasil}

Hasil deskriptif dilakukan untuk data kekuatan tungkai, data koordinasi mata kaki, dan data kemampuan menggiring bola dalam permainan sepakbola pada permainan sepakbola. Rangkuman hasil analisisnya tercantum dalam tabel 1 sebagai berikut :

Tabel 1.

Rangkuman hasil analisis deskriptif data tiap variabel.

\begin{tabular}{|l|c|c|c|c|c|c|}
\hline \multirow{2}{*}{\multicolumn{1}{|c|}{ Variabel }} & \multicolumn{7}{|c|}{ Nilai Statistik } \\
\cline { 2 - 7 } & $\mathbf{N}$ & Mean & Sd. & Min. & Max. & Range \\
\hline Kekuatan tungkai & 30 & 68,3200 & 12,64498 & 45,40 & 85,50 & 40,10 \\
\hline Koordinasi mata kaki & 30 & 15,4667 & 3,94561 & 11 & 22 & 11 \\
\hline Menggiring bola & 30 & 10,9113 & 1,90194 & 9 & 15 & 6 \\
\hline
\end{tabular}

Dari tabel di atas, maka dapat dikemukakan gambaran data tiap variabel sebagai berikut :

a. Untuk data kekuatan tungkai, diperoleh nilai rata-rata 68,3200 , standar deviasi 12,64498 , nilai minimum 45,40 , nilai maksimum 85,50, dan range 40,10.

b. Untuk data koordinasi mata kaki, diperoleh nilai rata-rata 15,4667 , standar deviasi 3,94561 , nilai minimum 11 , nilai maksimum 50, dan range 20 .

c. Untuk data kemampuan menggiring bola, diperoleh nilai rata-rata 10,9113 , standar deviasi 10,9113 , nilai minimum 9 , nilai maksimum 15, dan range 6 .

\section{Pembahasan}

Penelitian ini bertujuan untuk mengetahui adakah hubungan antara kekuatan tungkai, dan koordinasi mata kaki, dengan kemampuan menggiring bola dalam permainan sepakbola pada mahasiswa Pendidikan Kepelatihan Olahraga FIP UBHARA JAYA. Analisis data penelitian yang digunakan untuk menguji hipotesis terdiri atas analisis korelasi sederhana dan korelasi ganda. Untuk memperjelas hubungan antara variabel bebas dan terikat maka dilakukan analisis regresi.

1. Hubungan kekuatan tungkai terhadap kemampuan menggiring bola dalam permainan sepakbola pada mahasiswa Pendidikan Kepelatihan Olahraga FIP UBHARA JAYA.

Berdasarkan hasil penelitian menunjukkan bahwa ada hubungan yang signifikan antara kekuatan tungkai dengan kemampuan menggiring bola dalam permainan sepakbola pada mahasiswa Pendidikan Kepelatihan Olahraga FIP UBHARA JAYA. Dengan $r$ hitung sebesar (0.647). Hasil penelitian tersebut menunjukkan bahwa kekuatan tungkai mempengaruhi kemampuan menggiring bola dalam permainan sepakbola. Semakin besar kekuatan tungkai seseorang, maka kemampuan menggiring bola akan semakin cepat. Kekuatan merupakan komponen yang sangat penting untuk meningkatkan kondisi fisik secara keseluruhan karena kekuatan merupakan daya pengerak setiap aktivitas fisik. Disamping itu kekuatan memegang peranan penting melindungi atlet dari kemungkinan cedera. Dalam melakukan tendangan, kekuatan otot tungkai mempunyai peranan yang sangat penting terhadap keberhasilan tumpuan. Maka dari penjelasan diatas dapat di jelaskan bahwa kekuatan otot tungkai berhubungan dengan hasil menggiring bola dalam permainan sepakbola dikarenakan tekanan yang dihasilkan oleh tungkai yang kuat akan menghasilkan hasil yang maksimal.

2. Hubungan koordinasi mata kaki terhadap kemampuan menggiring bola dalam permainan sepakbola pada mahasiswa Pendidikan Kepelatihan Olahraga FIP UBHARA JAYA.

Hasil data dan pengujian hipotesis, penelitian ini membuktikan bahwa ada hubungan yang signifikan antara 


\section{e-ISSN: 2657-0703 dan p-ISSN: 2085-5389}

koordinasi mata kaki terhadap kemampuan menggiring bola dalam permainan sepakbola pada mahasiswa Pendidikan Kepelatihan Olahraga FIP UBHARA JAYA. Dengan $r$ hitung sebesar (0.633). Hasil penelitian tersebut menunjukkan bahwa koordinasi mata kaki mempengaruhi kemampuan menggiring bola dalam permainan sepakbola, Semakin baik koordinasi mata kaki seseorang, maka semakin baik pula kemampuan menggiring bola akan semakin pada mahasiswa Pendidikan Kepelatihan Olahraga FIP UBHARA JAYA, dan sebaliknya semakin kurang baik koordinasi mata kaki, semakin kurang baik pula kemampuan menggiring bola pada mahasiswa Pendidikan Kepelatihan Olahraga FIP UBHARA JAYA.

3. Hubungan kekuatan tungkai dan koordinasi mata kaki terhadap kemampuan menggiring bola dalam permainan sepakbola pada mahasiswa Pendidikan Kepelatihan Olahraga FIP UBHARA JAYA.

Hasil data dan pengujian hipotesis, penelitian ini membuktikan bahwa ada hubungan yang signifikan antara kekuatan tungkai dan koordinasi mata kaki dengan kemampuan menggiring bola dalam permainan sepakbola pada mahasiswa Pendidikan Kepelatihan Olahraga FIP UBHARA JAYA. Dengn $r$ hitung sebesar (0.827). Kekuatan tungkai diperlukan untuk menghasilkan tenaga yang maksimal dalam melakukan menggiring bola. Untuk menghasilkan keterampilan menggiring bola yang baik di tuntut untuk memiliki kekuatan otot tungkai yang baik. Kekuatan otot tungkai pada mahasiswa Pendidikan Kepelatihan Olahraga FIP UBHARA JAYA akan menghasilkan keterampilan menggiring bola dengan baik. Hal ini sejalan dengan hasil penelitian yang membuktikan bahwa kekuatan otot tungkai berhubungan signifikan dengan kemampuan menggiring bola dalam permainan sepak bola. Kekuatan otot tungkai diperlukan dalam melakukan rangkaian gerakan pada saat menggiring bola. Selain untuk tumpuan, tungkai digunakan sebagai ayunan dalam melakukan rangkaiam gerakan menggiring bola, yaitu dari gerakan awal sampai akhir.
Tahapan-tahapan gerakan menggiring bola merupakan satu kesatuan gerak yang dinamis dan tidak terputus-putus. Tingkatan baik atau tidaknya koordinasi gerak seseorang tercermin dalam kemampuannya untuk melakukan suatu gerakan dengan terampil. Seorang atlet dengan koordinasi yang baik bukan hanya mampu melakukan suatu keterampilan secara sempurna, akan tetapi juga mudah dan cepat dalam melakukan keterampilan yang masih baru baginya. Koordinasi yang baik dapat mengubah dan berpindah secara cepat dari pola gerak satu ke pola gerak yang lain sehingga gerakannya menjadi efektif. Berbagai pendapat di atas dapat disimpulkan bahwa koordinasi adalah suatu kemampuan yang dimiliki seseorang (atlet) dalam memadukan berbagai macam gerak yang berbeda-beda, dengan kesulitan yang berbeda, tetapi dilakukan secara cepat dan tepat. Fungsi koordinasi adalah menghasilkan satu pola gerakan yang serasi, berirama dan kompleks maka dari itu fungsi latihan koordinasi sangat penting untuk meningkatkan kemampuan tersebut. Sedangkan koordinasi mata kaki yaitu kemampuan seseorang dalam mengintegrasikan antara pandangan mata yaitu mata sebagai pemegang fungsi utama untuk melihat objek (bola) dan sasaran, kemudian kaki sebagai gerak untuk melakukan gerakan sesuai yang diinginkan yaitu menggiring bola dalam permainan sepakbola

\section{SIMPULAN DAN SARAN}

Berdasarkan analisis data dengan perhitungan statistik dan hasil pengujian hipotesis serta dari pembahasan, maka hasil penelitian ini disimpulkan sebagai berikut :

1. Kekuatan tungkai memberi hubungan terhadap kemampuan menggiring bola pada Mahasiswa Pendidikan Kepelatihan Olahraga FIP UBHARA JAYA.

2. Koordinasi mata kaki memberi hubungan terhadap kemampuan menggiring bola pada Mahasiswa Pendidikan Kepelatihan Olahraga FIP UBHARA JAYA.

3. Keseimbangan memberi hubungan terhadap kemampuan menggiring bola pada Mahasiswa Pendidikan Kepelatihan Olahraga FIP UBHARA JAYA. 
4. Kekuatan tungkai, koordinasi mata kaki dan keseimbangan memberi hubungan terhadap kemampuan menggiring bola pada Mahasiswa Pendidikan Kepelatihan Olahraga FIP UBHARA JAYA.

Berdasarkan hasil penelitian yang disimpulkan tersebut di atas, maka disarankan kepada :

1. Bagi Pelatih dan Pembina olahraga, agar di dalam memilih atlet sepakbola yang ingin dikembangkan harus memperhatikan unsur kekuatan tungkai, koordinasi mata kaki dan keseimbangan sebagai penunjang dalam melakukan permainan sepakbola.

2. Bagi atlet, untuk meraih prestasi yang baik dalam permainan sepakbola memerlukan kerja keras dan latihan yang kontinyu dan berkaitan dengan teknik dasar permainan sepakbola.

3. Fakultas Ilmu Keolahragaan merupakan suatu wadah untuk memperoleh ilmu yang berhubungan dengan olahraga, sehingga hasil penelitian ini dapat dijadikan ilmu yang berguna sebagai bahan masukan.

\section{DAFTAR RUJUKAN}

Rusli Lutan. (2000). Dasar-Dasar kepelatihan. Dirjen Pendidikan Dasar dan Menengah. Jakarta : Depdikbud.

Sajoto, M. 1995. Peningkatan dan pembimbingan kekuatan kondisi fisik. semarang: Dahara Prize

Sukatamsi . 2000. Teori dan Praktek Sepakbola I. Surakarta. UNS Press.

Salim, Agus, 2008. Buku Pintar Sepakbola. Bandung : NUANSA

Mukholid, Agus. 2007. Pendidikan Jasmani Olahraga dan Kesehatan. Surakarta: PT Ghalia Indonesia Printing.

Sugiyono. 2010. Metode Penelitian Pendidikan. Bandung: Penerbit ALFABET

Koger, Robert. 2007. Latihan Dasar Andal Sepakbola Remaja. Klaten. PT. Saka Mitra Kompetensi.

Nugraha, Andi Cipta. 2012. Mahir Sepakbola. Bandung. Nuansa Cendekia.

Riduwan, 2005. Prosedur penelitian. Jakarta. PT. Rineka Cipta.

Ismaryati. (2006). Tes dan Pengukuran Olahraga. Surakarta : Lembaga Pengembangan Pendidikan dan UPT UNS Press.

Nurhasan. (2001). Tes dan Pengukuran Dalam Pendidikan Jasmani. Jakarta : Depdikbud 